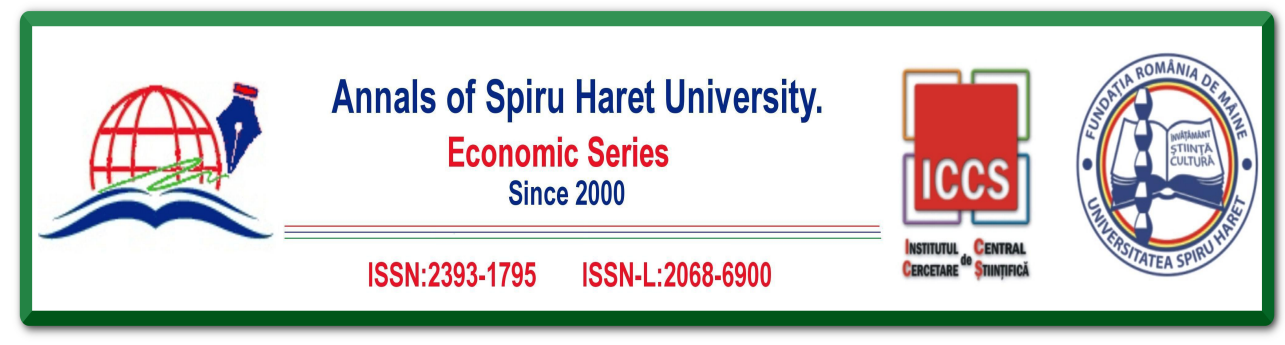

Issue 1/2019

\title{
THE OPINIONS AND PREFERENCES OF THE EUROPEAN BUYERS ON THE FURNITURE AND FURNITURE ACCESSORIES MARKET
}

\author{
Beatrice Georgeta PETRACHE (LANG)', \\ Camelia Maria ISMANĂ-ILIȘAN², Raluca CRET,OIU ${ }^{3}$ \\ ${ }^{1}$ Transilvania University of Braşov, Inter-disciplinary Doctoral School, \\ B-dul Eroilor No. 29, Brașov, România, Tel.: +40268.413.000, \\ Fax: +40268.410.525, Email: b.petrache@simausrom.com \\ ${ }^{2}$ Transilvania University of Brașov, Inter-disciplinary Doctoral School, \\ B-dul Eroilor No. 29, Brașov, România, Tel.: +40268.413.000, \\ Fax: +40268.410.525, Email: cismana@yahoo.com \\ ${ }^{3}$ Spiru Haret University, Faculty of Economic Sciences, Fabricii Street, \\ No. 46G, Bucharest, 030045, Romania, Tel.: +40212.169.793, \\ Fax: +40213.169.793, Email: raluca.cretoiu@yahoo.com
}

How to cite: PETRACHE (LANG), B. G., ISMANĂ-ILIȘAN, C. M., CREȚOIU, R. (2019). "The Opinions and Preferences of the European Buyers on the Furniture and Furniture Accessories Market." Annals of Spiru Haret University. Economic Series, 19(1), 95-114, doi: https://doi.org/10.26458/1916

\footnotetext{
Abstract

In this article we aim to analyze the preferences and opinions of European furniture buyers in the context of Germany, Italy, Poland, France and Austria being among the top 10 world furniture manufacturers, accounting for over 19\% of the world production and 60\% of the European one. We have developed this research given that the furniture industry is an important sector in the economy, employing about one million people at the level of the European Union, in 130,000 companies in the field. The furniture segment is also well represented in the field of innovation also, accounting for $12 \%$ of the applications for design registration in the European Union Intellectual Property Office (EUIPO). This
} 


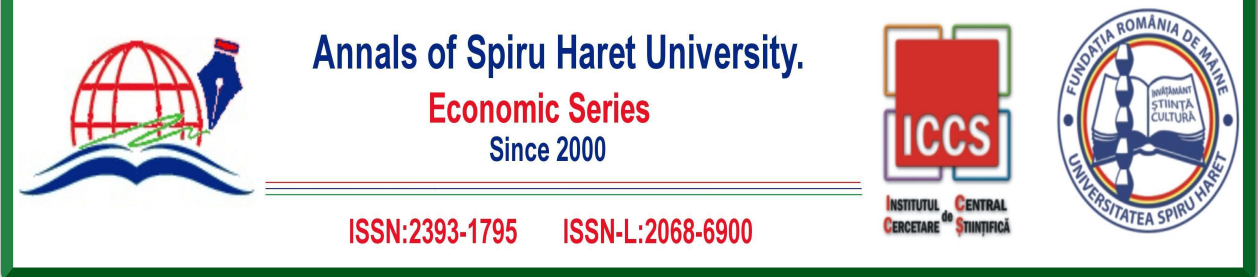

Issue 1/2019

also reflects on the production of furniture, currently 2/3 of the world's leading peak production coming from Europe. The research is of a quantitative nature, the technique adopted is the interview, and the research tool is the questionnaire. The purpose of the research is to identify the way and the level at which European consumers' value furniture accessories in the general context of furniture quality assessment in conjunction with the need for accessory information.

Keywords: accessories; furniture; European market; furniture industry

JEL Classification: M31, L68

\section{Introduction}

European furniture production has a high level of sophistication and, in the opinion of some specialists, a certain cyclicality, being sensitive to the economic circumstances [CSIL, 2014]. After overcoming with great difficulties the economic crisis that arose 10 years ago, the European furniture industry is in the process of being revived, existing at the EU level a set of 19 measures envisaged with the purpose to promote the quality of furniture, of which five compulsory mechanisms, six optional ones and eight voluntary ecolabels. Although they are aimed at market transparency and consumer awareness of decision-making, these measures are strongly different from one another.

The European furniture sector, in the world market, is advantaged by its renown and its production oriented towards the top segment. Internally, there are significant opportunities for most European countries. A condition for their exploitation is the uniform development of the sector and the avoidance of consolidating a position which is limited to the supply of raw materials, semi-finished products and products for the lower sector. For this, attention needs to be focused as well on research and the development of innovative products.

The quantitative research realized and presented in this article has as references the hypotheses generated by a previous qualitative research and aims at identifying the way and the level at which European consumers value furniture accessories in the general context of the furniture quality assessment in combination with the need for relevant information regarding the accessories. 


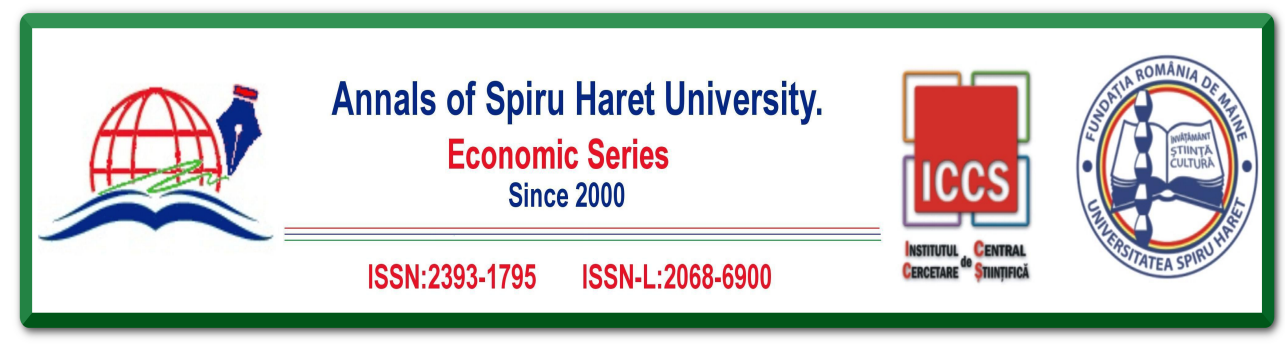

Issue 1/2019

Through this quantitative research, we intend to verify the hypotheses resulting from the qualitative research, namely to ascertain whether the opinions expressed by the major European furniture producers and traders are in consonance or, as the case may be, in dissonance with the actual behaviour of the consumers and their attitude in relation to furniture accessories, as they are considered items more or less important within the purchasing decision.

\section{Literature Review}

Consumer behaviour is reflecting the way in which different attitudes and opinions can affect the decisional process of customers taking account of particular situations over different markets and product/services types. As regarding furniture products consumption, the factors that are influencing buying decisional process and consumption are both from the individual, psychological layers of the consumers personality and from the external, cultural and economic influence.

Urban type consumers are developing cultural traits that predispose them to consumption models based on performance and self-management of time [Gârdan, et al., 2016].

Consumers have access to different information on a large scale due to the development of new communication technologies. From this respect, in the furniture industry a growing role for communicating the right amount of information have the labels used for products. In a research made on 26 subjects regarding the visual attention and perception on environment, workers respect and customer health, results have been showing that significant differences appear regarding the time spent looking at label areas and the impact in decision and consumption [Pérez-Belis, et al., 2018]

Competition among furniture producers and retailers has tremendously risen in the last years, as well as globally and on European local market. From this point of view, the effort to differentiate and obtain a certain position on the market is crucial for the optimization of the relationship with customers. Techniques of visual merchandising have been employed, consumers being sensible to this technique. For furniture products studies have been showing that eye-catching windows display, temperature, fragrance, lighting and music, room setting display, merchandise display, fixtures, signages, accessories and store front are the factors that influence most the decision of customers and their in store buying behaviour [Mehta \& Chugan, 2016; Wan \& Toppinen, 2016; Oblak, et al., 2017]. Other studies have 

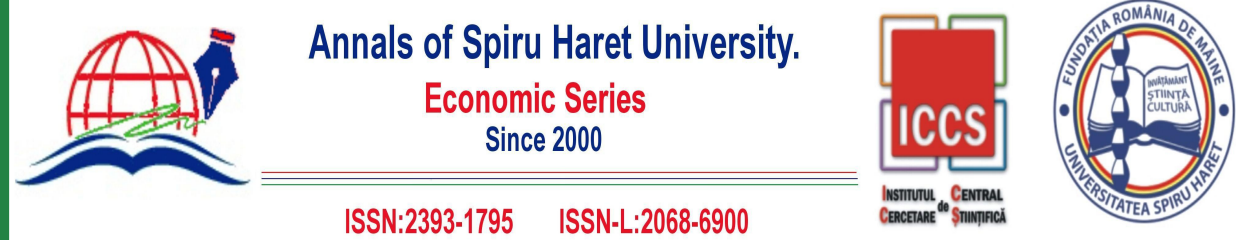

\section{Issue 1/2019}

shown that different elements of visual merchandising are affecting more product categories, like furniture and apparel. Window display affects the buying behaviour for both categories of products, the same with front store design, shelf display and creative combination of colours [Mehta \& Chugan, 2016; Jang, et al., 2018].

An important trend on the furniture global market is represented by the development of technologies such as internet of things, big data analytics, cloud computing etc. All these are having implications on the development of new models for e-commerce logistics and supply chain management, offering all kinds of possibilities to consumers and retailers alike [Yu, et al., 2017; Barčić, et al., 2016].

As regarding other factors that are shaping future trends of furniture consumption, we can assess the effort of furniture retailers to improve the environmental sustainability through the adoption of production systems, global international standards and modern innovative practices that are able to conserve required natural resources. [Zutshi, et al., 2016]

The new shape of consumer preferences about materials and new furniture accessories are showing that modern consumers are orienting themselves towards lightweight furniture and the use of lightweight wood-based materials in furniture design. [Knauf, 2015]

Consumers in the field of furniture production and retail are developing otherwise consumption models that are characteristic for the circular economy. The implementation of different business models in this context offers the possibility to the producers to achieve a sustainable development and consumption [Cheng, et al., 2018; Osburg, et al., 2015; Militaru, 2010].

Among business approaches that are optimizing also the consumption and sustainable production of furniture products we can mention life cycle optimization through an optimized transport system and the use of alternatives raw materials during the manufacturing of medium density particleboard [Iritani, et al., 2015; Liker, et al., 2016]. Retailers and furniture producers as well are developing new ways of staff management as qualitative managerial and executive staff is a prerequisite for improving the company competitiveness [Stefanov, 2017; Loučanová, et al., 2018], as an important part of the customer satisfaction being delivered by a modern trained staff.

Modern consumers are developing a behaviour based on the speed of information processing and concern for a sustainable consumption [Ivasciuc \& Epuran, 2015; Tescașiu, et al., 2018]. Loyalty and the emotional attachment 98 


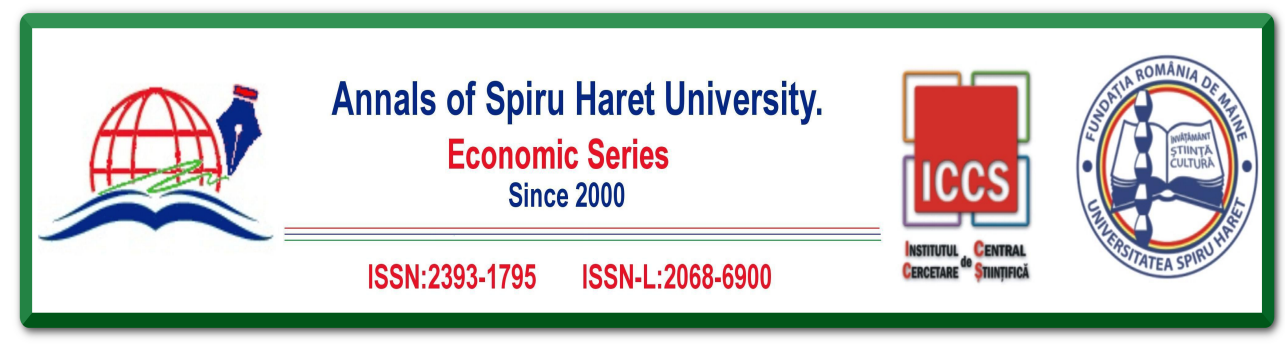

Issue 1/2019

towards brands are built on variables that are concerning the differentiation among competition in terms of staff support, creativity and innovative design [Cătoiu, et al., 2012; Oke, et al., 2016].

\section{Theoretical Background}

The quantitative research was conducted by sample type survey, and the questionnaire was used as a tool for data collection [Cătoiu, 2009]. Initially, the study was designed to be carried out on a sample of 500 people, without being representative for the entire population of the European Union given the size of the sample and the chosen sampling method [Harris, 2014]. Due to some difficulties encountered, especially in terms of costs, the vast territory to be covered and the high rate of non-responses in the online environment, 389 questionnaires were actually administered and completed.

The questionnaires were administered directly at the entrance to four large hypermarket stores located as follows: two in Austria (Linz and Vienna), one in Germany (Passau) and another in Switzerland (Lausanne). These stores sell furniture from most European countries. Thus, the researched population is made up of the visitors of the major stores specialized in the sale of furniture, over 18 years of age. The sampling was a non-probabilistic type one [Bernecker, 2013] given that it was not possible to establish a measurement step or other method to give each survey unit the chance to be part of the sample [Malhotra, 2002], but only an estimate of time, respectively an individual every 30 minutes.

The purpose of the research was to identify the way and the level at which European consumers' value furniture accessories in the general context of furniture quality assessment, combined with the need for accessories related information.

The overall objective of the research was to determine consumer's orientation regarding the importance of furniture accessories in furniture valuation and in the decision-making processes of purchasing furniture produced in the European space.

The specific objective of the research was to achieve the profile of the European furniture buyer, having as the central reference element (pivot) the preference for accessories.

The overall hypotheses of the research, as derived from the previous qualitative research, are:

H1. Consumers differentiate furniture produced in Europe by material quality, accessories and design elements; 


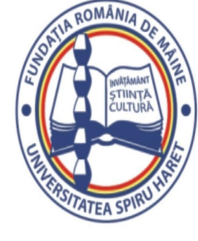

\section{Issue 1/2019}

H2. European consumers perceive the importance of technology and know-how in furniture manufacturing at a high level;

H3. European consumers prefer to address specialized retail shops rather than directly to furniture manufacturers;

H4. Non-European furniture is increasingly preferred by buyers on the EU market due to the progress in terms of quality and design;

H5. European buyers view accessories as essential elements in the decision to choose and buy furniture;

H6. European buyers use the brand as a risk mitigation method before buying;

H7. European buyers increasingly prefer metallic accessories that make the connection with the natural environment (rust-like, metal-like aspect, made of sandblasted or mat metal) instead of glossy metals;

H8. The presence in the promotional messages for furniture of information and images containing accessories is in line with customer's expectations.

The research questionnaire contained a total of 12 questions, of which eight referred to aspects about the hypotheses presented, the others focusing on certain aspects regarding the purpose of the store visit and the age, the income and the house of each respondent.

The collected data were centralized and sorted into the Excel program, and the analysis and interpretation were performed by similitude and differentiation, depending on the opinions expressed through the answers.

\section{Results and Discussions}

The interviewees offered the following answers at the shops' entrance about the purpose for which they came to the store (Fig. 1):

The interviewed consumers differentiate European furniture from the one produced outside the European borders, as such:

-Between $63 \%$ and $73 \%$ (an average of $70 \%$ ) of the respondents say that they easily recognize the quality and design elements of the European furniture, between $16 \%$ and $19 \%$ (an average of $17 \%$ ) say they recognize only part of the furniture, seeking additional information for a better recognition, and $13 \%$ of the respondents do not recognize the European furniture, but they also look for information to identify it. 


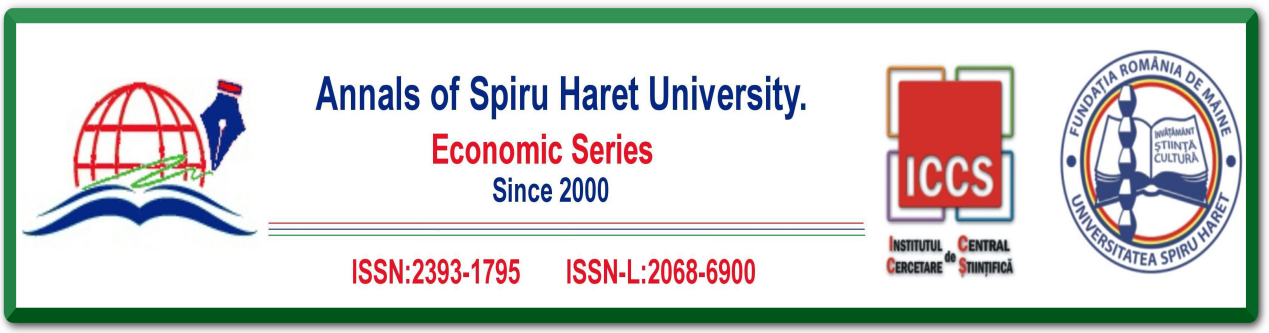

Issue 1/2019

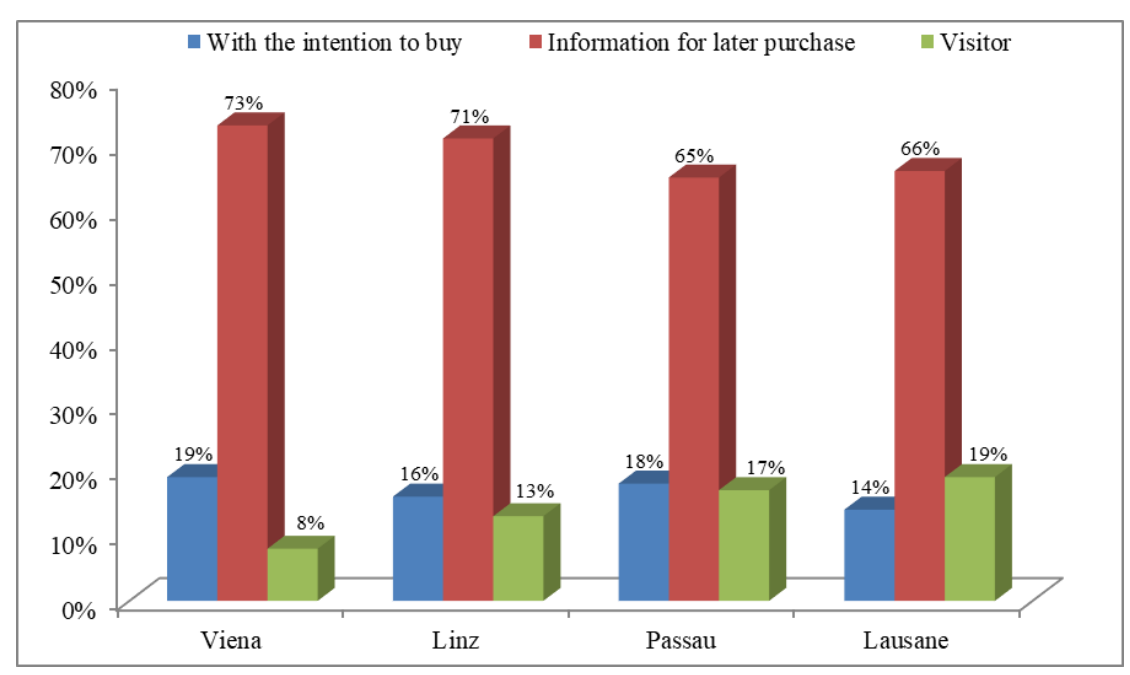

Fig. 1. Distribution of interviewed people according to the purpose declared at the store entrance

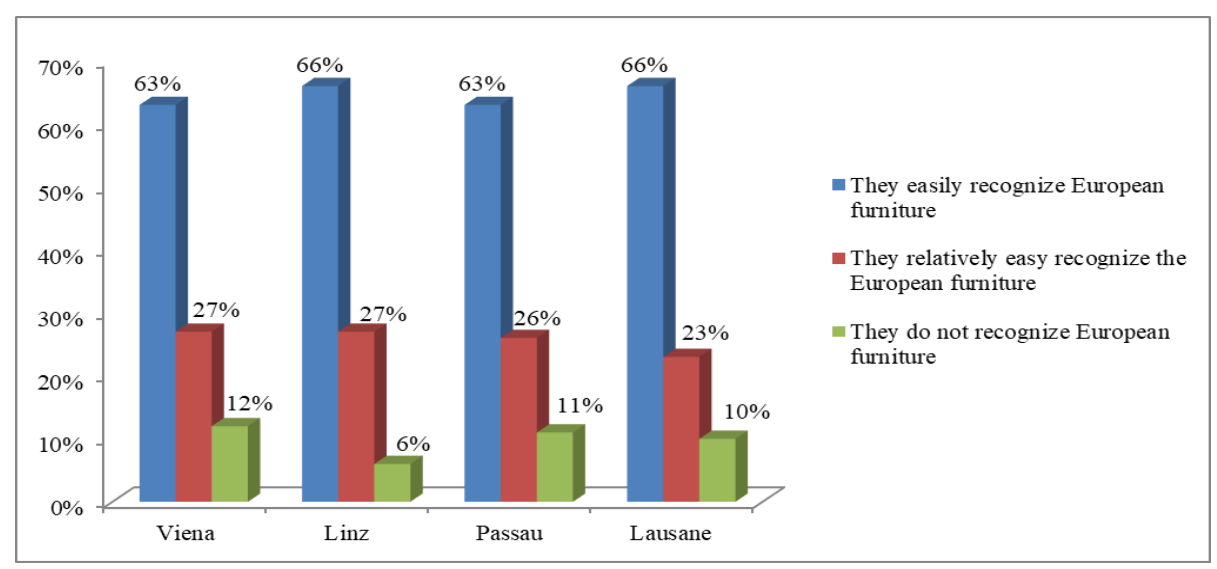

Fig. 2. Distribution of respondents according to the European furniture recognition degree 

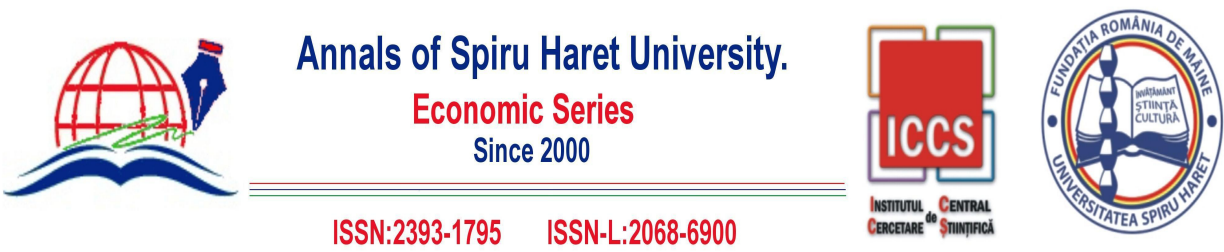

\section{Issue 1/2019}

Relevant to this research is the fact that - among the respondents who recognize European furniture - between $35 \%$ and $47 \%$ (an average of 38\%) indicate accessories among the elements of quality and design, the other quality reference elements being shown in figure 3 .

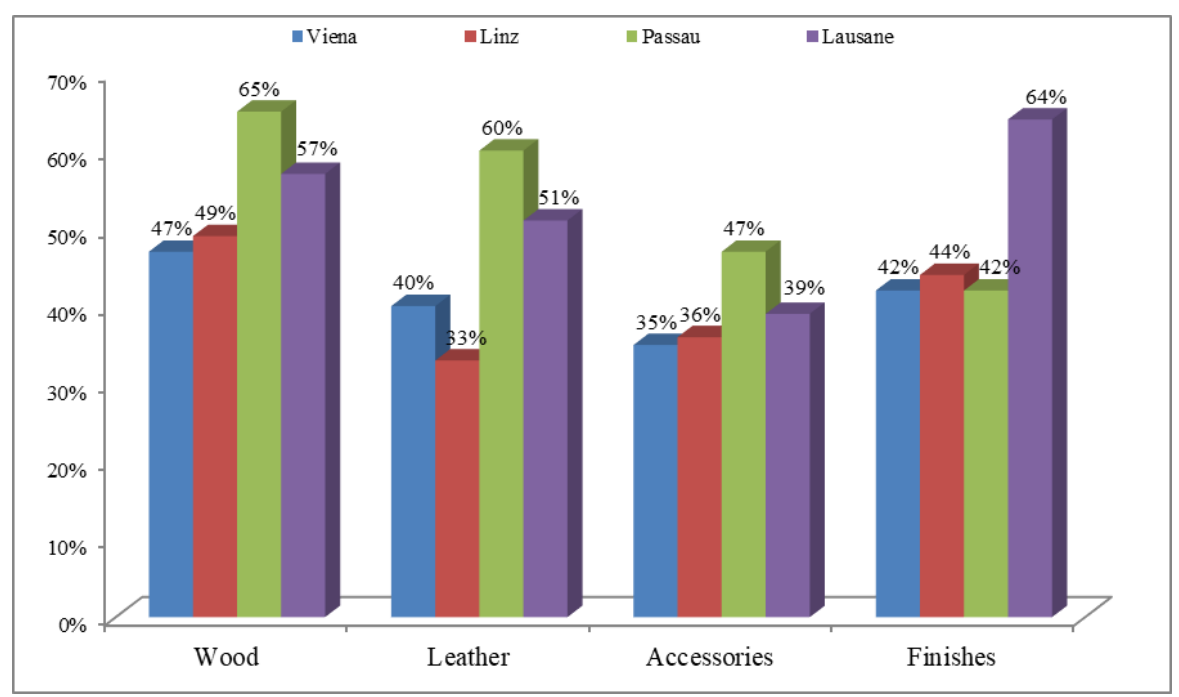

Fig. 3. Distribution of respondents according to their preference for materials, accessories and finishes

The interviewees use as elements of furniture differentiation, apart from the above-mentioned ones, the specific European design (between $73 \%$ and $89 \%$ ), the brand (between $64 \%$ and $74 \%$ ), as well as other non-listed criteria (between $6 \%$ and $9 \%$ ).

This analysis shows that most consumers differentiate furniture made in Europe by quality of materials, accessories and design elements. Accessories hold an important place in the overall furniture evaluation, i.e. about $40 \%$ on average, which is a confirmation of the value created by the producers at a level that is superior to their effort resulting from the qualitative research, i.e. about $17 \%$. 

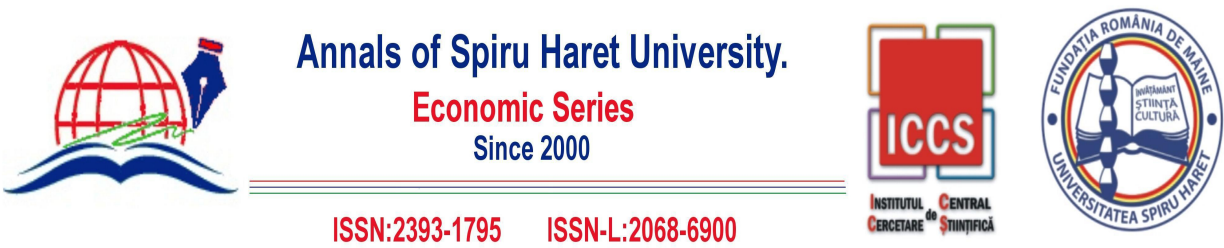

Issue 1/2019

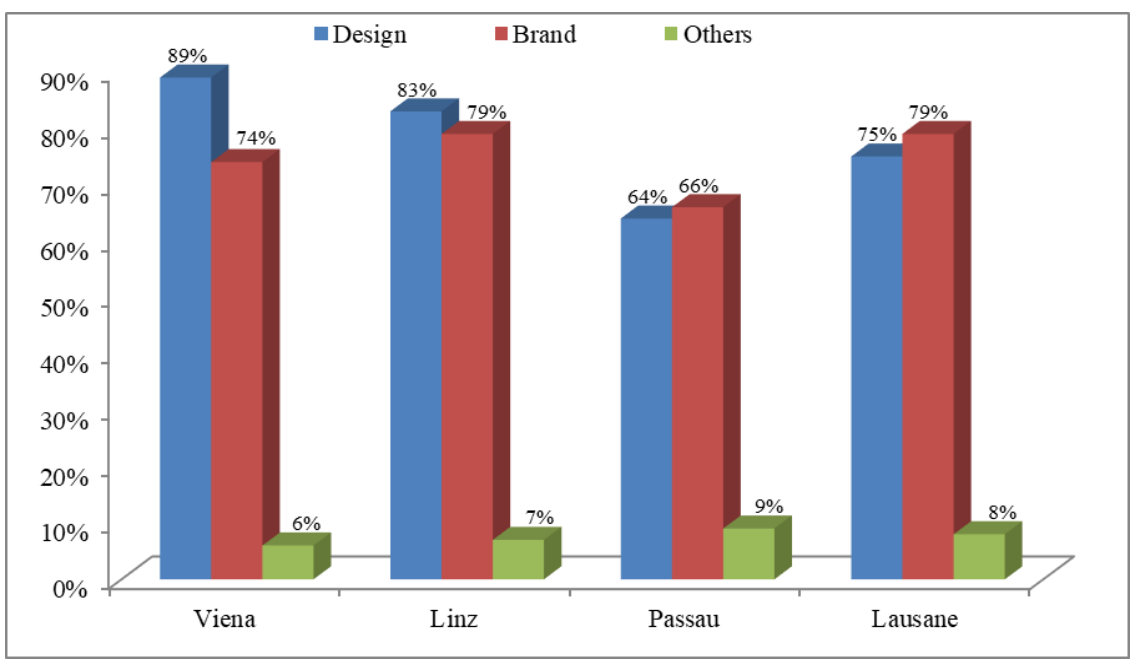

Fig. 4. Distribution of respondents according to the importance given to furniture design and brand

Hence, the $\mathrm{H1}$ general hypothesis, according to which consumers differentiate furniture produced in Europe through quality of materials, accessories and design elements, is accepted. H5 hypothesis, according to which accessories play an important role in the appreciation of the furniture and in the purchasing decision, is accepted as well.

As far as consumer's opinions regarding the elements that make up the value of European furniture are concerned, they are oriented towards know-how and technology, with very small differences, as shown in Figure 5.

It can be noticed that the $\mathbf{H} 2$ hypothesis, namely European consumers perceive the importance of technology and know-how in furniture manufacturing at a high level, is confirmed and accepted, given that, on average, about $49 \%$ of the respondents appreciate the know-how elements and $45 \%$ the technology, the other aspects being insignificant. 


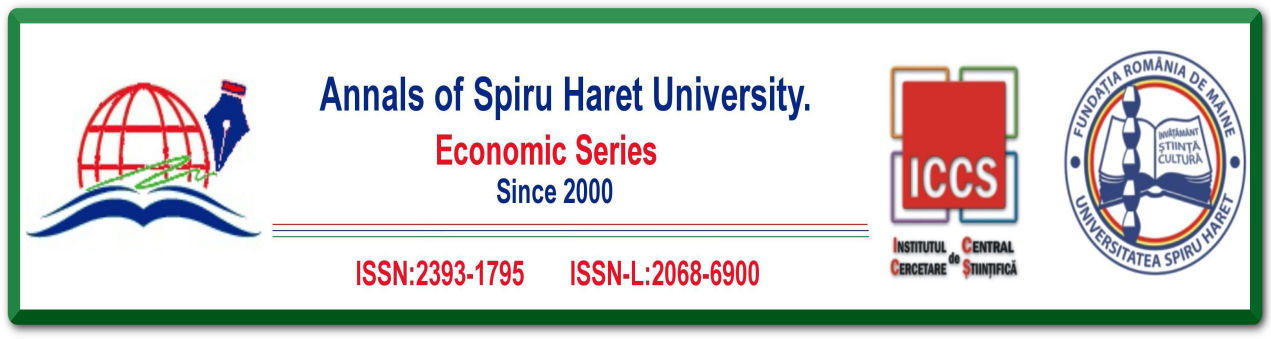

Issue 1/2019

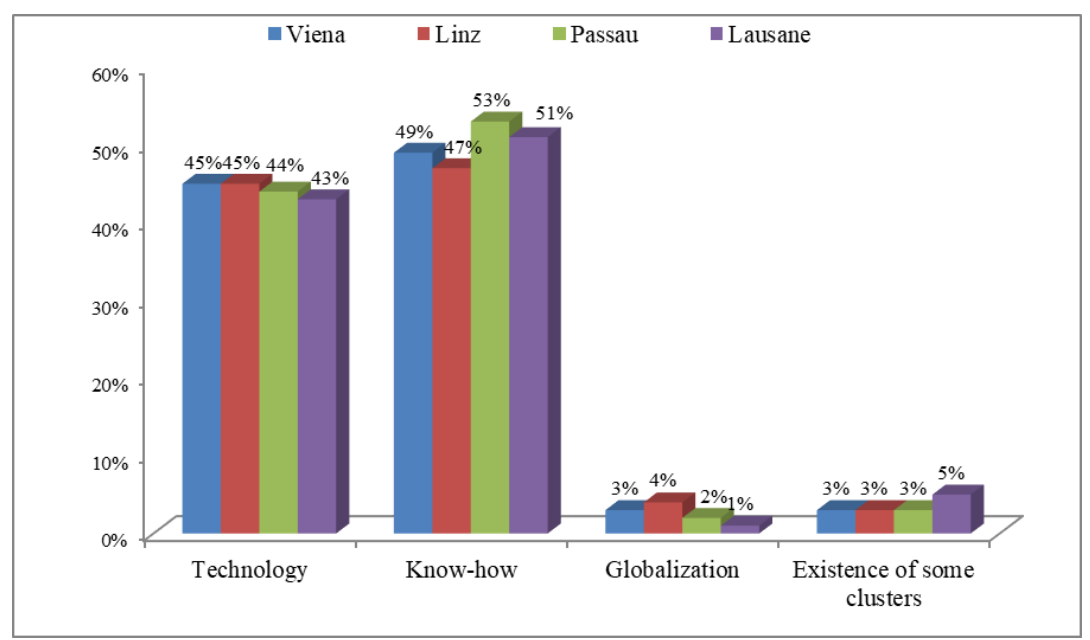

Fig. 5. Distribution of respondents according to their perception regarding the role of technology and know-how elements in furniture manufacturing

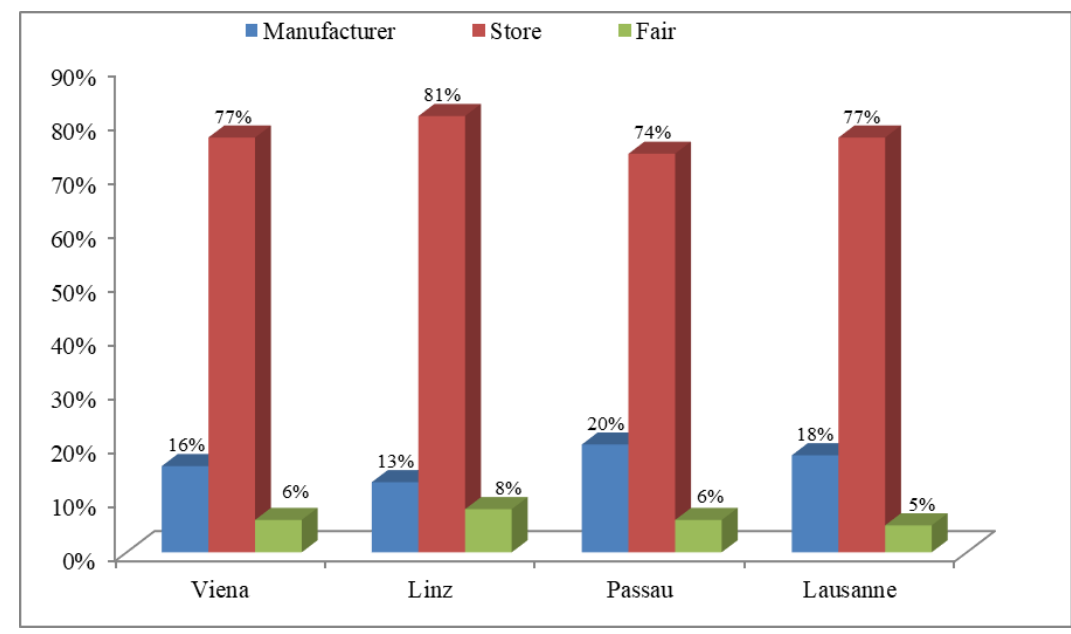

Fig. 6. Distribution of buyers depending on where they prefer to buy furniture from 


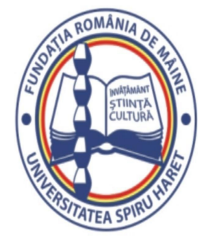

Issue 1/2019

We also find the existence of the prerequisites for accepting the H6 hypothesis, according to which consumers use the brand as a risk mitigation method before the purchase, in that the brand is mentioned as an important element of positioning the furniture. Respondents preferred places to buy furniture are specialized store, followed by factory store and fairs (Fig. 6).

From this analysis it follows that the general hypothesis H3, according to which European consumers prefer to address retail specialized stores rather than directly to the furniture manufacturers, is accepted.

Although managers see the quality of the non-European furniture marketed on the European market as rising, consumers perceive the price as a central element of competitiveness that could determine them to buy such furniture (Fig. 7).

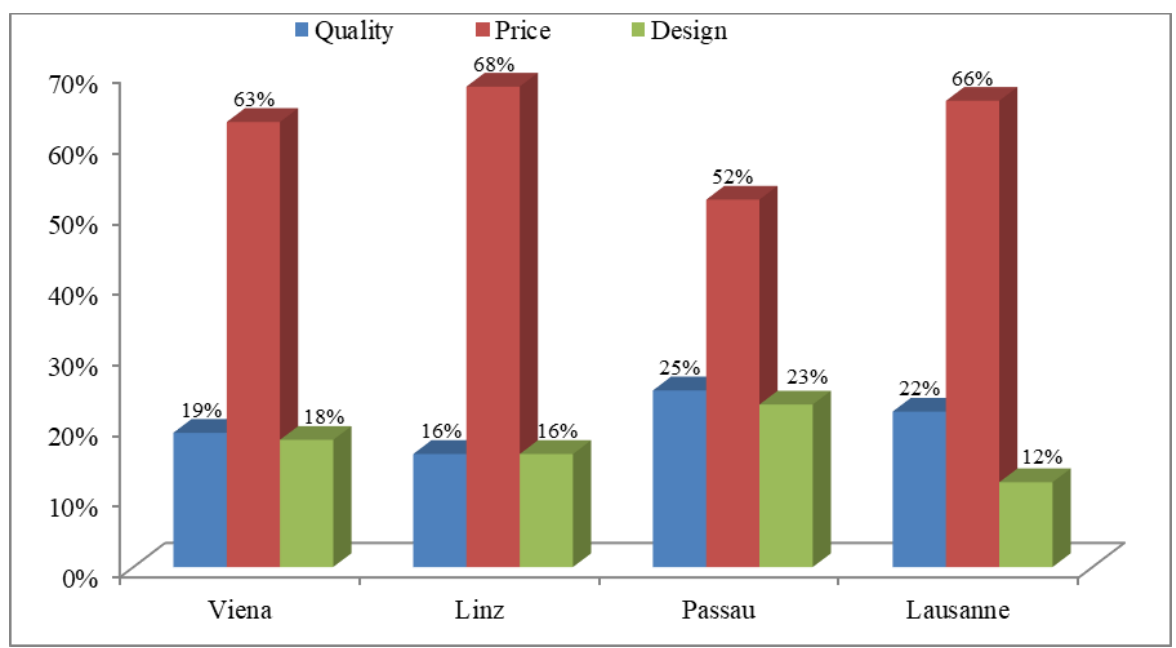

Fig. 7. Perception of the quality, price and design of non-European furniture at the level of furniture buyers

Producers' perception is a technical one, and the quality threat is real, as it results from the qualitative research implemented earlier. In response, consumers' perception has an economic foundation and, as a result, is first directed towards prices that are significantly lower in Asian furniture, at least. 


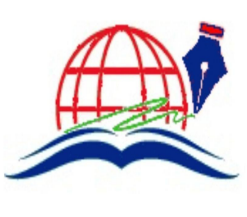

Annals of Spiru Haret University.

Economic Series

Since 2000
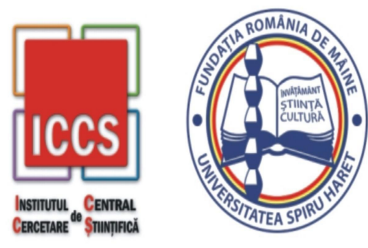

Issue 1/2019

Synthesizing, we believe that the H4 hypothesis, Non-European furniture is increasingly preferred by buyers on the European market due to the progress made in quality and design, is rejected in terms of the two elements, but it is accepted in terms of price, according to the options expressed by the interviewees.

From our point of view, which is based on technical assessments, this hypothesis can be accepted, as furniture coming from the Asian countries, especially from China, is of increasing quality, this aspect not being reflected directly proportional into the price, which is why buyers still perceive price as a central element for the competitiveness of the non-European furniture, as it was found in the H3 hypothesis.

Regarding the importance of accessories in the purchasing decision, the answers have the following distribution (Fig. 8.)

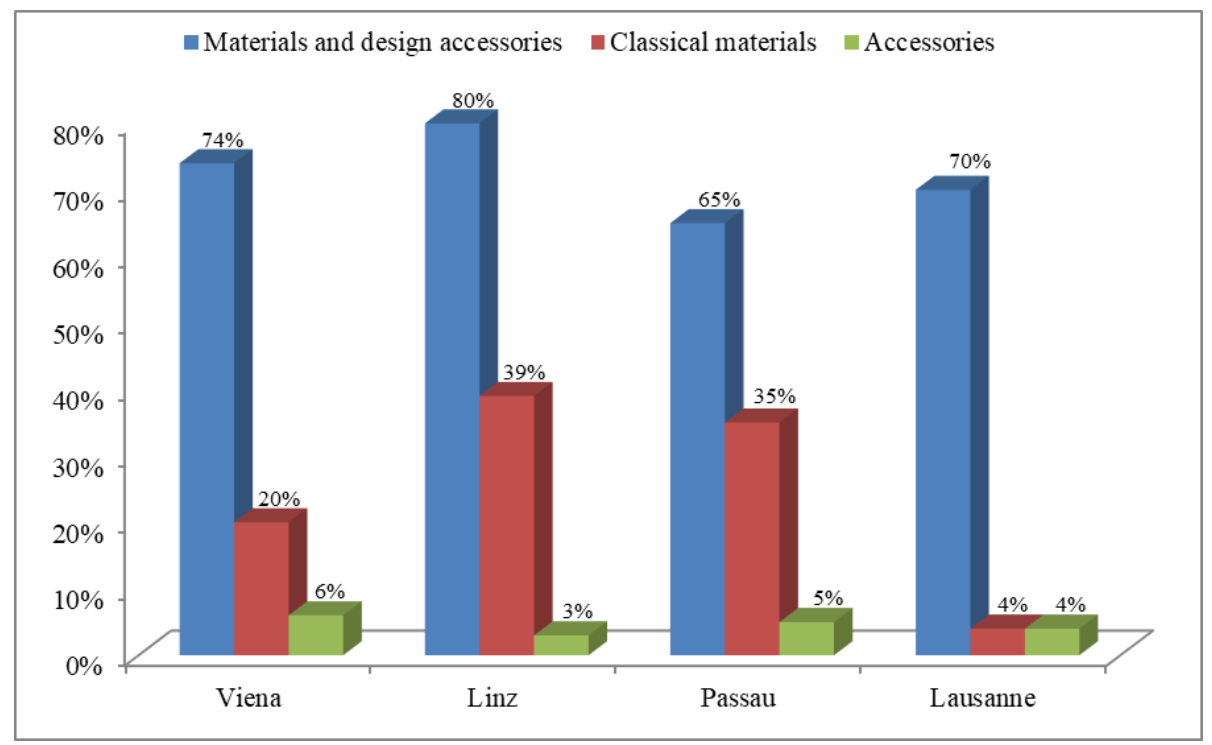

Fig. 8. Distribution of answers regarding the importance of accessories in the purchasing decision

It is found that a significant percentage $(74 \%)$ associates within the product the three elements, including accessories, in order to make a decision, and the 106 


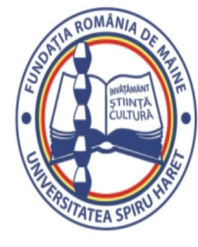

Issue 1/2019

accessories alone are decisive in the selection process of only 5\%. The conclusion that can be drawn from this is that most buyers consider the accessories as important to the idea of product as the so called "basic" materials and the design. We believe that the $\mathrm{H5}$ hypothesis, according to which European buyers view accessories as essential elements in the decision to choose and buy furniture, is accepted / confirmed.

Most respondents stated that the brand is the main element that gives them confidence when they decide to buy furniture. The association between brand and price is natural, the price being second in weight, this fact signifying the relative importance of the price in the purchase decision and not necessarily its use as a risk mitigation method (Fig. 9).

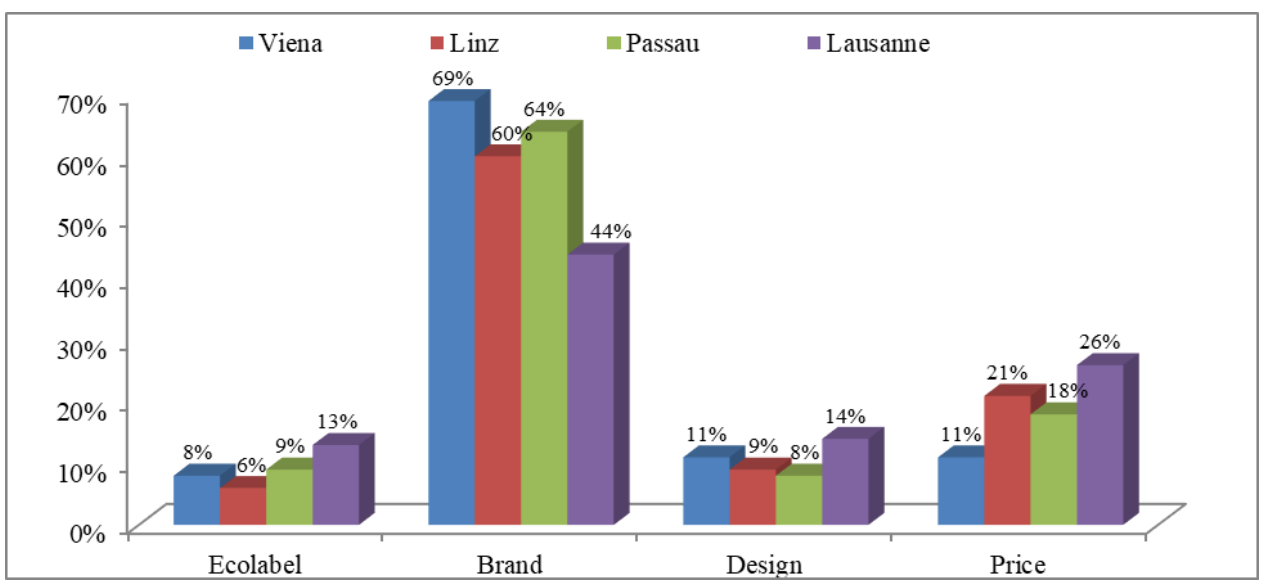

Fig. 9. Distribution of responses regarding the elements used by buyers as risk mitigation elements before buying

It follows that the $\mathrm{H6}$ hypothesis, according to which Buyers use the brand name as a method and risk mitigation element before the purchase, is accepted.

Regarding the materials of which they prefer the accessories to be made, the desires of the potential buyers are predominantly oriented towards the mat and the seemingly "rusty" metal (Fig. 10). 


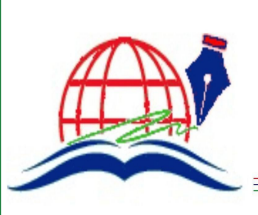

Annals of Spiru Haret University.

Economic Series

Since 2000

ISSN:2393-1795 ISSN-L:2068-6900
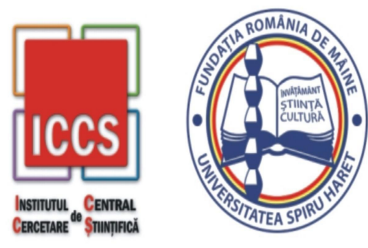

Issue 1/2019
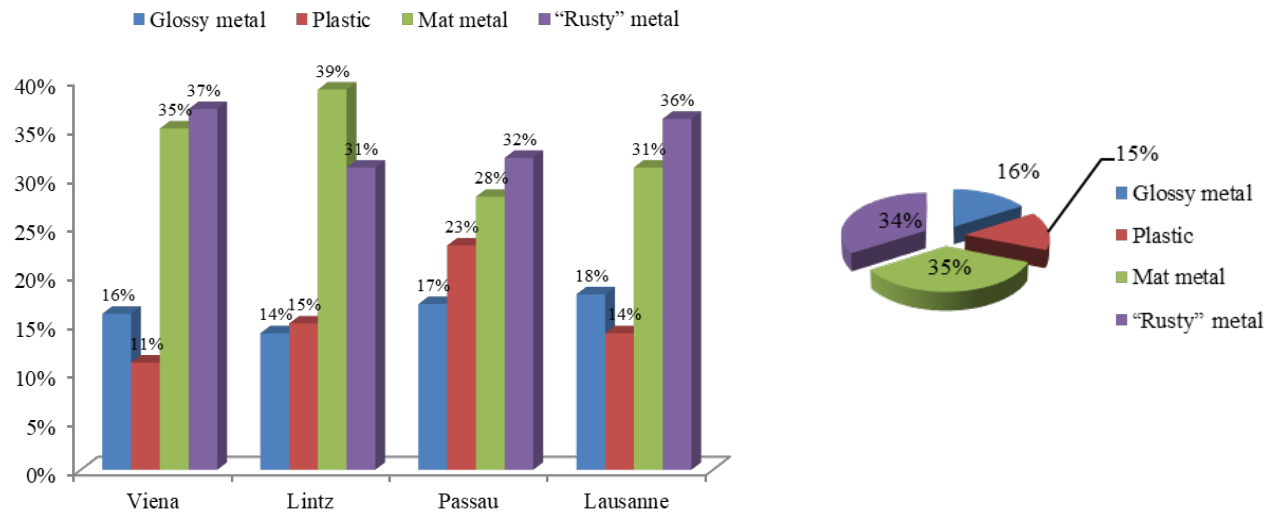

Fig. 10.a. The main materials preferred by buyers for the accessories

Consequently, the $\mathbf{H} 7$ hypothesis, according to which European buyers increasingly prefer metallic accessories that connect with or suggest the idea of originality and naturalness (rust-like, metal-like aspect, made of sandblasted or mat metal) instead of glossy metals, is accepted.

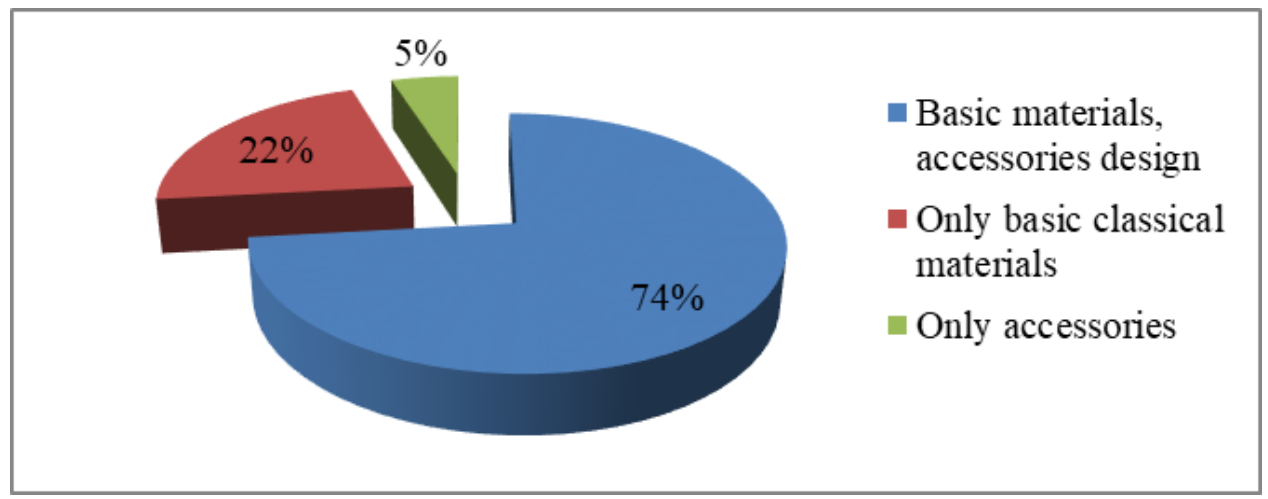

Fig. 10.b. Distribution of responses regarding the availability of accessory information in promotional materials 


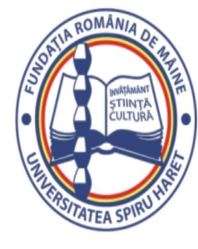

Issue 1/2019

The presence in the furniture promotional messages of some information and images containing accessories in accordance with customers' expectations is considered in qualitative research as a referential element, detaching itself as a hypothesis for quantitative research. Analyzing the answers expressed, there is a buyers' concern for finding complete and conclusive information about the furniture, including about the accessories.

Thus, it appears that most of the respondents appreciate the furniture accessories together and at the same level with the materials considered classical in the furniture industry (wood, leather, textiles, etc.).

In this context, the $\mathbf{H 8}$ hypothesis, according to which The presence in the furniture promotional messages of information and images containing accessories is in line with customer expectations, is accepted.

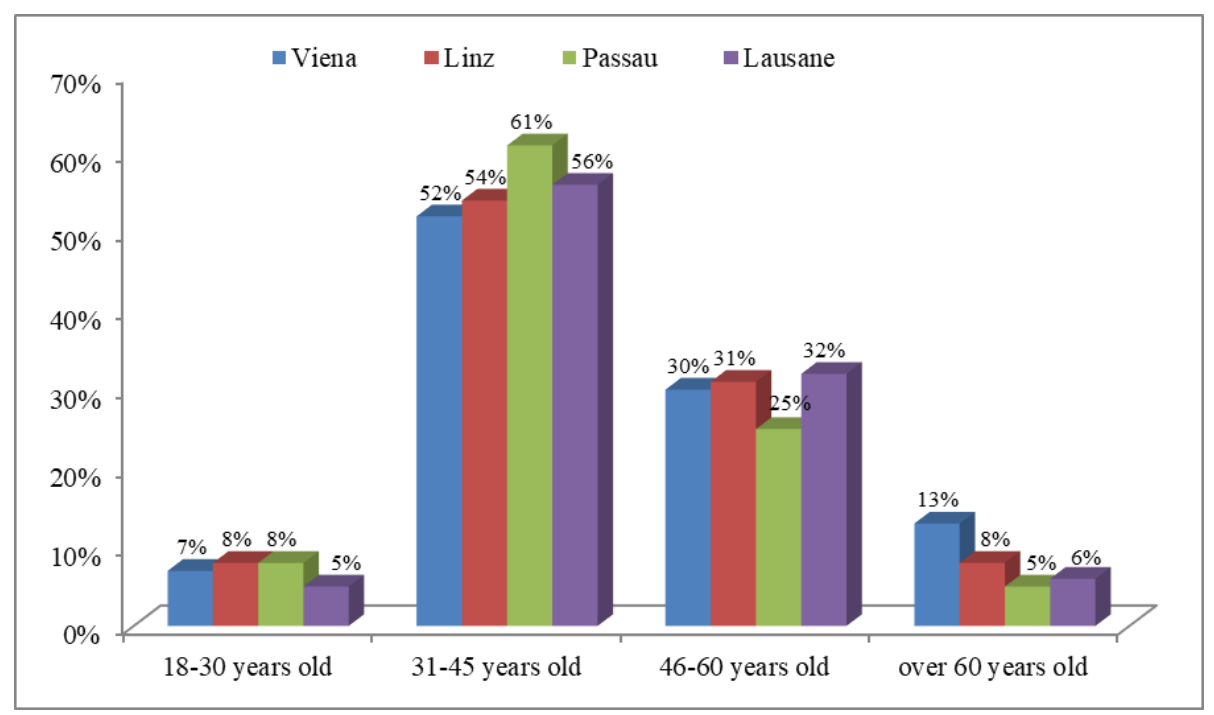

Fig. 11. Distribution of respondents by age

From the overall analysis of the results obtained and their significance, it results that the qualitative research carried out led to a series of plausible hypotheses, 


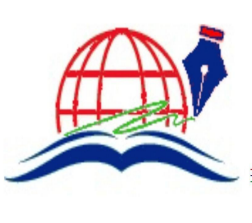

Annals of Spiru Haret University.

Economic Series

Since 2000
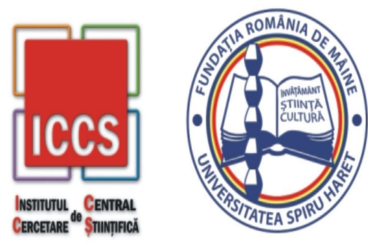

\section{Issue 1/2019}

which were fully confirmed through the quantitative research, which demonstrates that the producers and the big traders know consumers preferences, adapt to those, and sometimes anticipate them.

The distribution of respondents by age can be seen in Fig. 11.

We discover that the largest share of visitors in held by those from the 31-45 years age group, a thing what we consider to be normal, given that concerns about space furnishing are correlated with the age and income available within this category.

From the declared income point of view, we find the following distribution of respondents (Fig. 12):

Visitors with an income between 2,001 and 3,000 euros hold the largest share, followed by those with incomes between 1,001 and 2,000 euros. In terms of housing, over $50 \%$ of visitors said they live in a house (Fig. 13).

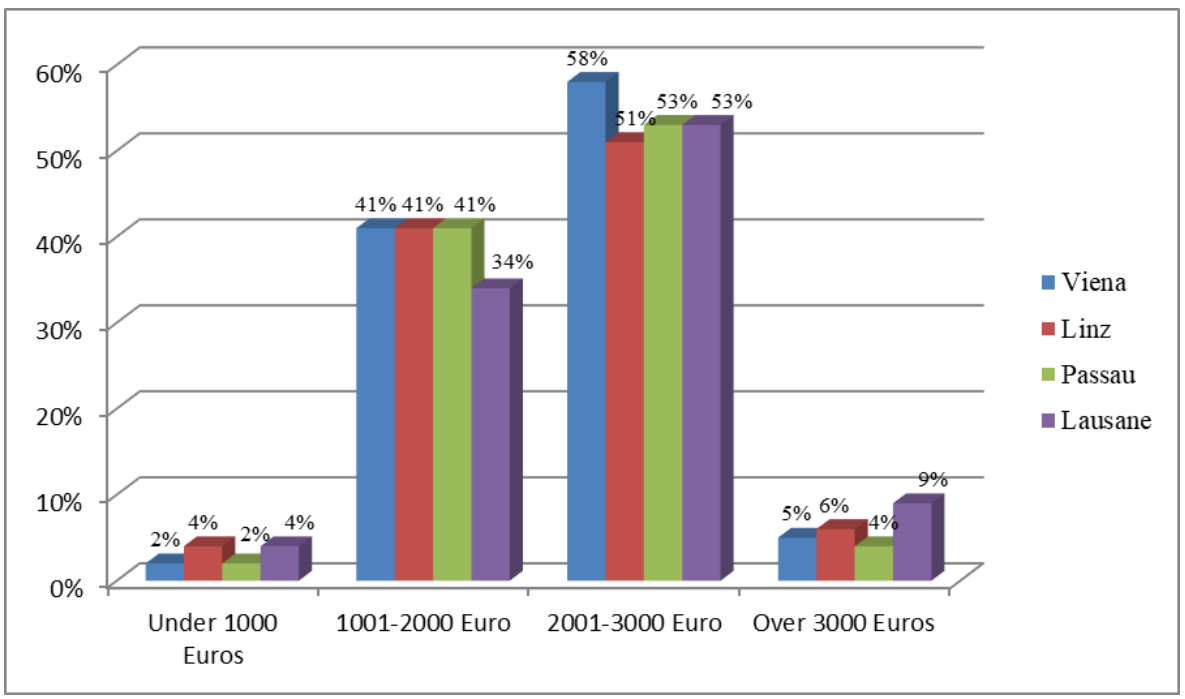

Fig. 12. Distribution of respondents by income 


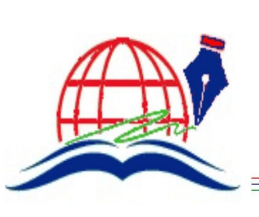

Annals of Spiru Haret University.

Economic Series

Since 2000

ISSN:2393-1795 ISSN-L:2068-6900

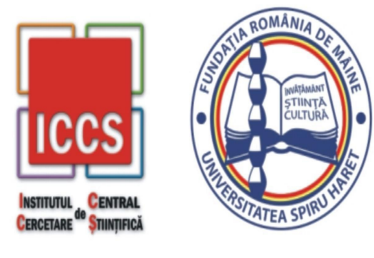

Issue 1/2019

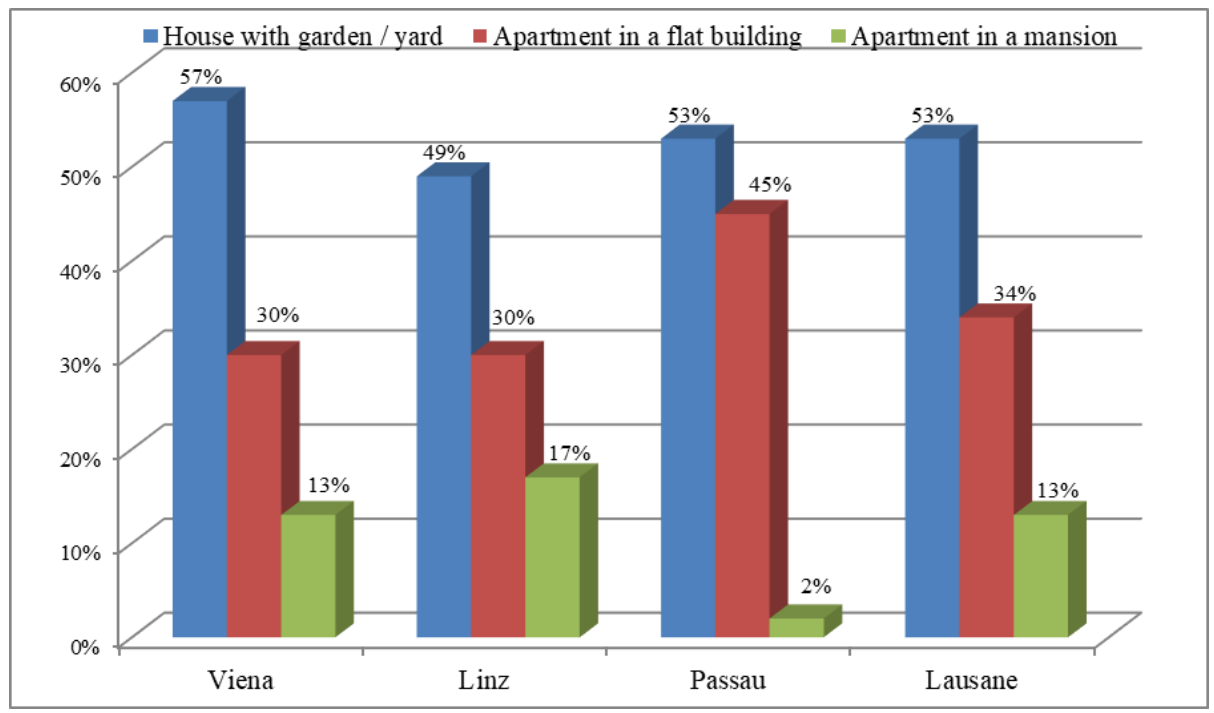

Fig. 13. Distribution of respondents by dwelling

More than $30 \%$ of the respondents say they live in an apartment located in a flat building, the rest say they live in apartments located in mansions. This is due to the fact that a large number of visitors came from neighbouring areas, small towns and periurban localities, respectively.

\section{The Profile of the European Furniture Buyer}

Based on the distribution of responses from each questionnaire and using the sorting and calculation functions available in Excel, the profile of the European furniture buyer has been developed, with the pivotal preference for accessories, respectively the importance of accessories in the purchasing decisions correlated with the type and appearance of the material from which they are made.

Thus, of the 389 respondents, 38\% consider accessories as important quality elements of the furniture and make the decision of purchasing taking into account as well this aspect. They easily recognize European manufactured furniture, they consider the brand an important element in mitigating or even eliminating the pre- 


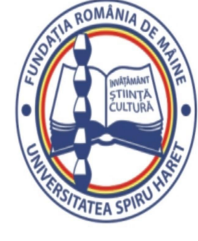

Issue 1/2019

purchase risk, they recognize and appreciate the role of technology and know-how in European furniture production, they are aware that non-European products are making good progress in terms of quality. Most of these buyers fall into the 46-60 years age group (57\%), followed by the $33-45$ years age group, with the other categories accounting for almost 10 per cent.

Of the respondents in the 46-60 years age category, $61 \%$ have an average monthly income between 2,000 and 3,000 Euros and $11 \%$ have an average monthly income over 3,000 Euros. Of the age group of $31-45$ years, $42 \%$ have an average monthly income between 2,001 and 300 Euros and 23\% have a monthly income of more than 300 Euros. Of the respondents who appreciate the accessories and take them into account in the purchase decision, $63 \%$ are women and $37 \%$ are men, 59\% live in a house, $14 \%$ live in a flat building, and $27 \%$ live in an apartment located in a mansion.

In this context, the profile of the European furniture buyer from the big stores, which appreciates the accessories in the general furniture evaluation, is the following:

- A person aged between 36 and 60, with an average monthly income of more than 2,000 Euros, mainly uses the brand for mitigating perceived risk, is well acquainted with European furniture, has confidence in technology and know-how in the manufacturing process, is not willing to buy non-European furniture just because it is cheaper.

- Seeks information that is consistent with their appreciative approach, that is, information that does not present materials and design in isolation, but which integrates furniture accessories into the whole of the product.

\section{Conclusions}

Research shows that furniture accessories acquire valences that harmoniously integrate into the value chain and implicitly into consumer's perception. Over $38 \%$ of the interviewed consumers consider the accessories to be as important as the so called "basic" materials, such as wood, leather, textile etc. Equally, accessories are desired and appreciated by consumers as elements that complete the furniture's aesthetics and design. Consumers appreciate European furniture alike in terms of materials and design, as well as technology and know-how. The technological aspects are appreciated at the level of finishes, style and accessories, the latter incorporating increasingly sophisticated and complex technologies. Quantitative research also reveals a number of managerial implications, especially in the 


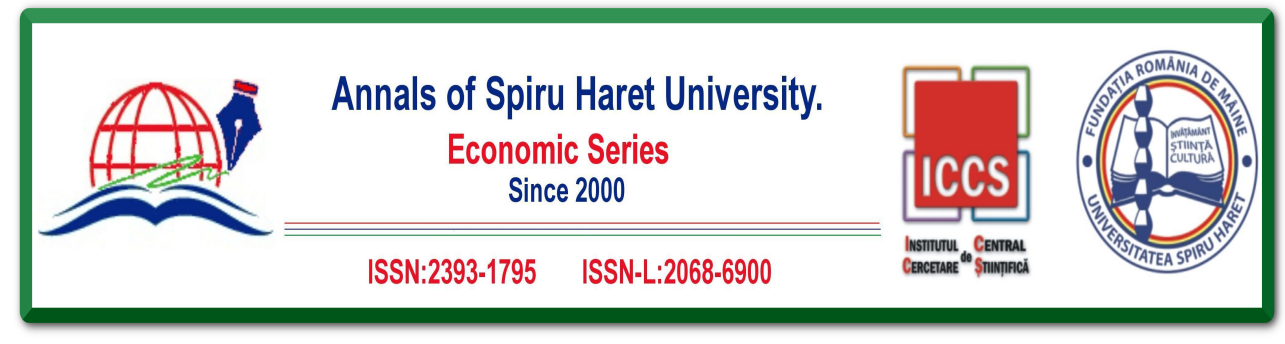

Issue 1/2019

management of the product-market portfolio, by integrating accessories into the overall furniture as a basic element that contributes to the ergonomics, operation and design of the products.

\section{References}

[1] Barčić, A. P., Motik, D., Oblak, L., \& Vlosky, R. (2016). "Management Activity Linkages to Innovation Deconstruction: An Exploratory Study of the Furniture Industry in Croatia." BioResources, 11(2), 3987-4005.

[2] Bernecker, M. Marketing: Grundlagen - Strategien - Instrumente, Deutsches Institut für Marketing, 2013.

[3] Cătoiu, I. (coord.). Cercetări de marketing - Tratat. Editura Uranus, București, 2009.

[4] Cătoiu, I., Gârdan, D. A., \& Geangu, I. P. (2012). "Customer Loyalty-Specific Features of Retail Activity in Bucharest." Annales Universitatis Apulensis-Series Oeconomica, 14(1), 1-25.

[5] Cheng, C. C., \& Chou, H. M. (2018). "Applying the concept of circular economyUsing the cultural difference of European consumers as an example." In 2018 IEEE International Conference on Applied System Invention (ICASI) (pp. 449-452). IEEE.

[6] Gârdan, D. A., Cătoiu, I., \& Gârdan, I. P. (2016). "Coordinates of the Culture Consumption in Urban Environment." Annales Universitatis Apulensis Series Oeconomica, 2(18), 1-10.

[7] Harris, F. D. The Complete Guide to Writing Questionnaires: How to Get Better Information for Better Decisions, I\&M Press, 2014.

[8] Iritani, D. R., Silva, D. L., Saavedra, Y. M. B., Grael, P. F. F., \& Ometto, A. R. (2015). "Sustainable Strategies Analysis through Life Cycle Assessment: A Case Study in a Furniture Industry." Journal of Cleaner Production, 96, 308-318.

[9] Ivasciuc, I. S., \& Epuran, G. (2015). "A Marketing Approach on How Continuous Processes Improvement Can Contribute to Hotel Business Organic Growth." Bulletin of the Transilvania University of Brasov. Economic Sciences. Series V, 8(2), 185-200.

[10] Jang, J. Y., Baek, E., Yoon, S. Y., \& Choo, H. J. (2018). "Store Design: Visual Complexity and Consumer Responses." International Journal of Design, 12(2), 105-118.

[11] Knauf, M. (2015). "Understanding the Consumer: Multi-Modal Market Research on Consumer Attitudes in Germany towards Lightweight Furniture and Lightweight Materials in Furniture Design." European Journal Of Wood And Wood Products, 73(2), 259-270., https://doi.org/10.1007/s00107-014-0866-9

[12] Liker, B., Stirn, L. Z., Bučar, D. G., \& Hrovatin, J. (2016). "Examination of Decision Factors in the Process of Buying Kitchen Furniture Using Conjoint Analysis." Wood Industry/Drvna Industrija, 67(2). 


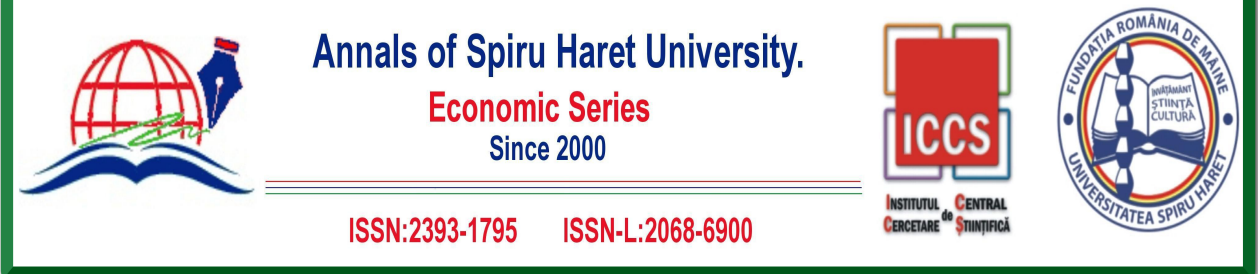

\section{Issue 1/2019}

[13] Loučanová, E., Olšiaková, M., \& Dzian, M. (2018). "Suitability of Innovative Marketing Communication Forms in the Furniture Industry." Acta Facultatis Xylologiae Zvolen res Publica Slovaca, 60(1), 159-171.

[14] Malhotra, K. N. Marketing Research: An Applied Approach, Pearson Education, 2002.

[15] Mehta, N., \& Chugan, P. K. (2016). "Visual Merchandising as Tool for Creating Differentiation for Furniture Outlets: Perceptual Mapping." Inter-disciplinary Issues for Empowering Trade, Industry and Society, Eds., Pawan K. Chugan, Deepak Srivastava, Nikunj Patel and Nirmal C. Soni, Excel India Publishers, New Delhi, 289-300.

[16] Militaru, M. (2010). "Leader and Leadership in the International Companies." Annals of Spiru Haret University, Economic Series, 1(3), 229-236.

[17] Oblak, L., Pirc Barčić, A., Klarić, K., Kitek Kuzman, M., \& Grošelj, P. (2017). "Evaluation of Factors in Buying Decision Process of Furniture Consumers by Applying AHP Method.” Drvna industrija: Znanstveni časopis za pitanja drvne tehnologije, 68(1), 37-43.

[18] Oke, A. O., Kamolshotiros, P., Popoola, O. Y., Ajagbe, A. M., \& Olujobi, J. O. (2016). "Consumer Behaviour towards Decision Making and Loyalty to Particular Brands." International Review of Management and Marketing, 6, 43-52.

[19] Osburg, V. S., Conroy, D., \& Toporowski, W. (2015). "Furnishing Sustainable Futures: An Exploration of How Furniture Manufacturers Can Demonstrate Sustainable Leadership." In 10th International Symposium on Sustainable Leadership, 2015.

[20] Pérez-Belis, V., Agost, M. J., \& Vergara, M. (2018). "Consumers' Visual Attention and Emotional Perception of Sustainable Product Information: Case Study of Furniture." In International Conference on Kansei Engineering \& Emotion Research (pp. 239-248). Springer, Singapore.

[21] Stefanov, Ts. Modern Aspects of the Bulgarian Economy in the EU Context. Current Problems of Development of Economic, Financial and Credit, Belgorod, Russia, 2017.

[22] Tescașiu, B., Epuran, G., Tecău, A., Chițu, I., \& Mekinc, J. (2018). "Innovative Forms of Economy and Sustainable Urban Development — Sharing Tourism." Sustainability, 10(11), $1-18$.

[23] Wan, M., \& Toppinen, A. (2016). "Effects of Perceived Product Quality and Lifestyles of Health and Sustainability (LOHAS) on Consumer Price Preferences for Children's Furniture in China." Journal of Forest Economics, 22, 52-67.

[24] Yu, Y., Wang, X., Zhong, R. Y., \& Huang, G. Q. (2017). "E-commerce Logistics in Supply Chain Management: Implementations and Future Perspective in Furniture Industry." Industrial Management \& Data Systems, 117(10), 2263-2286.

[25] Zutshi, A., Creed, A., Holmes, M., \& Brain, J. (2016). "Reflections of Environmental Management Implementation in Furniture." International Journal of Retail \& Distribution Management, 44(8), 840-859. 


\section{DOCTORAL AND POSTDOCTORAL PAPERS}


